\title{
Antifouling effect of two saturated copper coatings applied on carbon steel structures ${ }^{(\cdot)}$
}

\author{
P. S. Guiamet*,** y S. G. Gómez de Saravia*,***
}

\begin{abstract}
Biofouling is the colonization of man-made substrata by sessile organisms. The aim of this paper is to evaluate the performance of two antifouling saturated copper coating. Bioassays were carried out at a harbor in Argentine $\left(38^{\circ} \mathrm{O} 2^{\prime} \mathrm{S}\right.$ $\left.57^{\circ} 32^{\prime} \mathrm{W}\right)$. During six months, one series of pipes and panels were removed monthly to estimate the recruitment of macro and microfouling species and immediately replaced by clean ones. Another series was removed from the beginning of exposure to monitor the development of the established community (accumulative pipes and panels along six months). Data obtained from control (without a saturated copper coating) and saturated-copper coated pipes and panels were compared in order to estimate performance of the coating. One of two saturated copper coating demonstrated a good effect antifouling.
\end{abstract}

\section{Efecto antifouling de dos cubiertas saturadas de cobre aplicadas sobre estructuras de acero al carbono}

Resumen

Palabras clave

\begin{abstract}
El biofouling es la colonización por organismos sésiles en sistemas de sustratos hechos por el hombre. El objetivo fue evaluar el efecto antifouling de dos cubiertas saturadas de cobre. Los estudios se llevaron a cabo en un puerto de la Argentina $\left(38^{\circ} 02^{\prime} \mathrm{S}-57^{\circ} 32^{\prime} \mathrm{W}\right)$. Durante seis meses, una serie de caños y paneles fueron removidos mensualmente para estimar el reclutamiento de las especies del macro y microfouling, y fueron sustituidos inmediatamente por caños y paneles limpios. La otra serie de caños y paneles fueron removidas desde el inicio de la exposición en forma acumulativa durante los seis meses, para seguir el desarrollo de la comunidad. Los datos obtenidos de los controles sin cubierta y de los caños y paneles con las cubiertas saturadas de cobre fueron comparados para estimar el comportamiento antifouling de las mismas. Una de las dos cubiertas saturadas de cobre demostró un buen efecto antifouling.
\end{abstract}

Antifouling; Biofilms; Biofouling; Cubierta de cobre; Acero al carbono.

\section{INTRODUCTION}

Metal surfaces immersed in natural or industrial waters undergo a sequence of biological and inorganic changes as a consequence of accumulation process in the metal/solution interface that is not necessarily uniform in time or space ${ }^{[1]}$; in turn, these changes lead to the establishment of biofouling. An intensive control program to inhibit biofouling development in offshore platforms and piping is very important to prevent future problems ${ }^{[2]}$. The increase in off-shore oil extraction has created a special awareness about biocorrosion processes, as attested by several specialized publications and conferences ${ }^{[3}$ and 4$]$.

One of the most significant problems encountered in these systems is the growth of biofilms of heterotrophic aerobic bacteria and sulfate reducing bacteria (BRS) ${ }^{[5]}$. These are ubiquitous in our environment and occur in waterlogged soils, marine sediments, beneath macrofouling layers, etc., flourishing under anaerobic conditions ${ }^{[6]}$. Fungi, yeast, microalgae, protozoa $^{[7]}$ and macrofouling are also present ${ }^{[8 \text { and } 9]}$. Biofilms promote interfacial physicochemical reactions

\footnotetext{
(·) Trabajo recibido el día 1 de junio de 2007 y aceptado en su forma final el día 28 de abril de 2008.

* Instituto de Investigaciones Fisicoquímicas Teóricas y Aplicadas (INIFTA). UNLP-CCT. La Plata - CONICET, CC 16, Suc. 4 (1900), La Plata, Bs. As., Argentina. Tel: 54-221-4257430, Fax: 54-221-4254642. Argentina. e-mail: pguiamet@inifta.unlp.edu.ar.

** Consejo Nacional de Investigaciones Científicas y Técnicas (CONICET), Bs. As., Argentina.

*** Comisión de Investigaciones Científicas de la Provincia de Buenos Aires (CICBA).
} 
that are not normally favored under abiotic conditions $^{[10]}$.

Abiotic factors, characteristics of the seawater, the amount of organic matter and $\mathrm{pH}$, influence the distribution of colonizing microbial species in the resultant biofilm.

According to ${ }^{[11]}$, sessile bacteria monitored through bioprobe devices provide an experimental means of verifying the formation of microbial biofilm.

These industrial problems can be treated by different methods, including: cleaning the system, controlling the levels of planktonic and sessile bacteria, avoiding biofilm formation, using oxidizing biocides, soluble and natural biocides ${ }^{[12}$ and ${ }^{13]}$, and antifouling saturated copper coating.

Different authors have studied the biofouling of stainless steel and copper alloys immersed in polluted seawater ${ }^{[14-17]}$.

The use of appropriate sampling and monitoring strategies complemented with field and laboratory microbiological techniques is necessary to achieve a proper understanding of the effects derived from microbial activity and the role of biofilms in the corrosion reaction, in order to apply effective control and prevention countermeasures ${ }^{[18]}$.

The goal of this work was to evaluate the performance of two antifouling saturated copper coatings. Bioassays were carried out in a harbor in Argentine

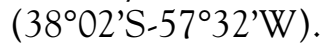

Microbiological techniques were applied, abiotic factors were studied, and light microscope and scanning electron microscope (SEM) observations of biological communities were made.

\section{MATERIALS AND METHODS}

Bioassays were carried out in Mar del Plata harbor

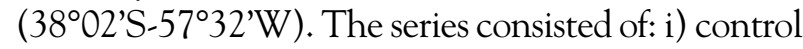
pipes (without copper) and pipes covered with saturated copper coating (A). A seamless carbon steel pipe of the kind habitually use in the oil industry was coated with 250-micron thick epoxy after heating at 200 ${ }^{\circ} \mathrm{C}$, a second 300 - micron thick layer of a polypropylene copolymer to function as adhesive between the epoxy and the third layer, which was about $60 \mathrm{~mm}$ thick and made of polypropylene with hollow glass microspheres. A 300-micron thick polypropylene film with necessary stabilizers was extruded onto this isolated pipe, and covered with $100 \%$ copper powder (grain size 45-63 microns) on its entire surface, wich would be in contact with the sea water. The copper powder was thus strongly adhered to polypropylene to avoid its rubbing off due to abrasion. The second series included ii) control panels (without copper) and panels covered with saturated copper coatings (B). Coating (B) was similar to $(A)$ in composition; however, it was not extruded but hand-spread onto the panel surfaces for the bioassays, (Figs.1 and 2). The samples were vertically hung from a floating dock, about 0.3 and $1.5 \mathrm{~m}$ below the water surface to allow colonization by fouling organisms. Every month one series (pipes and panels) was removed to estimate the recruitment of micro and macrofouling species, and was immediately replaced by a clean one. The other series were checked monthly (during six months) to assess and record the development of the biofouling community from the beginning of the exposition (accumulative panels). Table I show the sampling schedule used in this study.

\subsection{Laboratory analyses}

\subsubsection{Microbiological studies}

The samples were collected directly from the sampling site, refrigerated and sent to the laboratory immersed in seawater. Biofilm was removed from the sampling

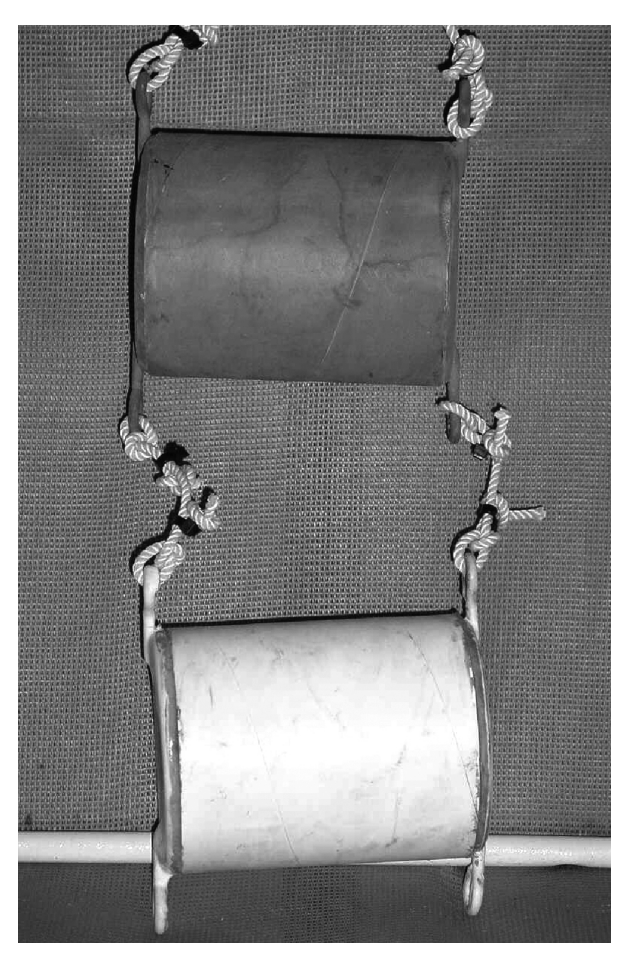

Figure 1. General view of the series of pipes before immersion. Top, pipe covered by saturated copper coating (A); Bottom, control pipe (without copper).

Figura 1. Vista general de las series de tubos antes de la inmersión. Arriba, tubo cubierto por una capa de cobre saturado (A); Abajo, tubo control (sin cobre). 


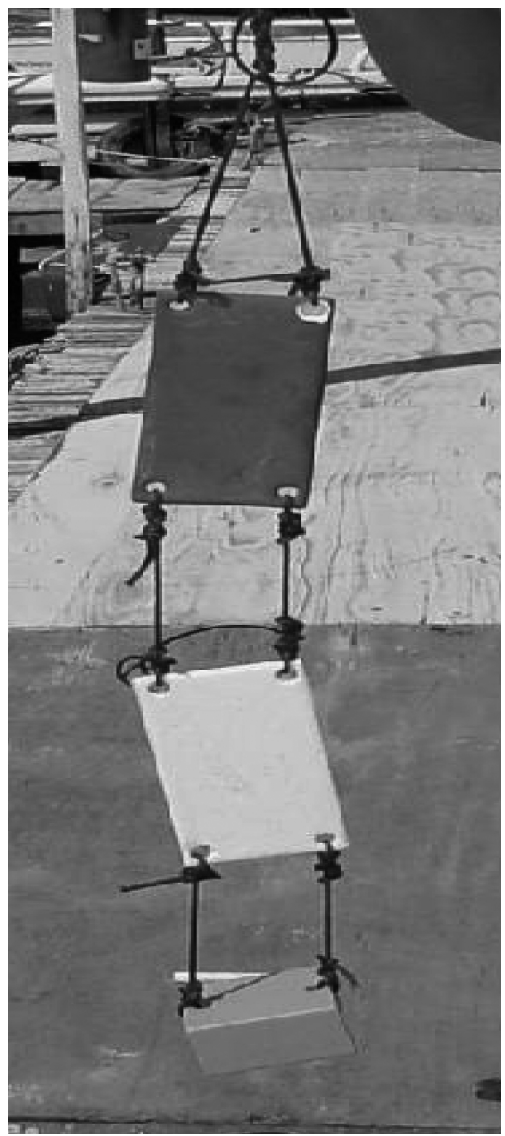

Figure 2. General view of the series of panels before immersion. Top, panel covered by saturated copper coating (B); Bottom, control panel (without copper).

Figura 2. Vista general de la serie de paneles antes de la inmersión. Arriba, panel cubierto con una capa de cobre saturado (B); Abajo, panel control (sin cobre).

Table I. Sampling schedule.

Month (M) Accumulative samples (AS) Monthly samples (MS)

Tabla I. Cronograma de muestreos. Meses (M), Muestras Acumulativas (AS), Muestras Mensuales (MS)

\section{Month}

$\begin{array}{lll}1^{\text {st }} & \text { Placement of samples } & \\ 2^{\text {nd }} & \text { Remove MS and AS } & \text { Restore MS } \\ 3^{\text {rd }} & \text { Remove two MS and AS } & \text { Restore MS } \\ 4^{\text {th }} & \text { Remove two MS and AS } & \text { Restore MS } \\ 5^{\text {th }} & \text { Remove two MS and AS } & \text { Restore MS } \\ 6^{\text {th }} & \text { Remove two MS and AS } & \text { Restore MS } \\ 7^{\text {th }} & \text { Remove two MS and AS } & \end{array}$

surface by scraping and suspended in physiological solution. Viable microorganisms were counted by standard techniques ${ }^{[6 \text { and } 19]}$ and different culture media were used ${ }^{[20]}$. Gram stains and biochemical test were performed on the samples.

\subsubsection{Microfouling and macrofouling studies}

The abundance of sessile species was estimated by recording their presence in the square cells or quadrates of a grid placed over the entire panel; sets of 10 random cells were considered statistically representative of the whole panel. New sets of random quadrates were used for each pipe and panel per month. Once the abundance for each species was estimated and recorded, it was expressed in a percentage scale. Five abundance categories were used: rare 1-25\%; scarce 25.1-50 \%; frequent 50.1$75 \%$; abundant $75.1-100 \%$ [21].

\subsubsection{Microscopic and scanning electron microscope (SEM) studies}

Observations of biological communities were made. Samples were observed under a JEOL JSM-T 100 Scanning Electron Microscope using conventional techniques ${ }^{[22]}$. Microfouling was observed under optical microscope (100x and 200x).

\subsection{Field studies}

Abiotic factors were recorded in the study area at the time of first immersion and at subsequent monthly intervals.

\section{RESULTS AND DISCUSSION}

Abundant fixation (approx. $80 \%$ ) was recorded on the pipe with copper coating (A). Macrofouling was represented by the sandy tubes of Corophium, ascidians both colonial, genus Botryllus, and solitary, genus Ciona, and algae of the species Enteromorpha intestinalis (Chlorophyta) and Polysiphonia (Rhodophyta). In terms of microfouling colonization, diatoms were the predominant adhesive organisms. Microbiological counts were high in both cases ${ }^{[23]}$.

The coating $(\mathrm{A})$ was not effective to prevent fixation of organisms in the six months (Fig.3); however, it was effective to prevent fixation of 


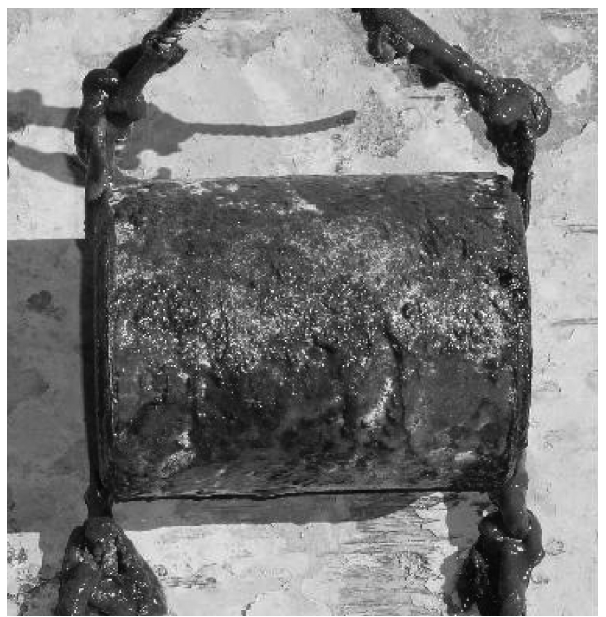

Figure 3. Pipe covered by saturated copper coating (A), after six month of immersion.

\section{Figure 3. Caño cubierto por una capa saturada de cobre $(A)$ después de seis meses de inmer- sión.}

organisms on a month-to-month basis, as shown by the analysis of monthly controls. In a chloride containing medium such as seawater a complex anodic layer structure that involves an inner $\mathrm{Cu}_{2} \mathrm{O}$ and an outer $\mathrm{Cu}(\mathrm{OH})_{2}$ layer is built. The structure of these anodic layers can be represented by a poorly hydrous inner $\mathrm{Cu}_{2} \mathrm{O}$ non-homogeneously covered by $\mathrm{Cu}(\mathrm{OH})_{2}$. Chloride ions absorbed on the copper surface and $\mathrm{Cu}(\mathrm{I})$ and $\mathrm{Cu}(\mathrm{II})$ soluble species are formed in the presence of oxygen. These ions have a marked biocidal effect ${ }^{[24]}$.

The coating (A) did not perform well for longerterm control of adhesion (Fig. 4). It is due that copper had high leaching speed, due to a fault in the technique aplication (extruded) so that the pipes were unprotected after 30 days of immersion., the performance might have been affected by the method used to apply the coating. The extrusion process like that coating A produces defects such as surface or internal cracking when the surface of extrusion splits or when the centre develops cracks or voids. The cracks are attributed to a state of tensile stress at the deformation zone. Therefore, defects due to incorrect stress distribution are frequently found after extrusion processes. Such tensile stress are absent in the panels with coating B which was not extruded but hand spread on to the panel ${ }^{[25]}$. This fault can be serious economic loss in the industry oil petroleum and offshore in its different processes of extraction, processing, distribution and storage is affected by serious problem derived from microorganisms and biofoluling processes.

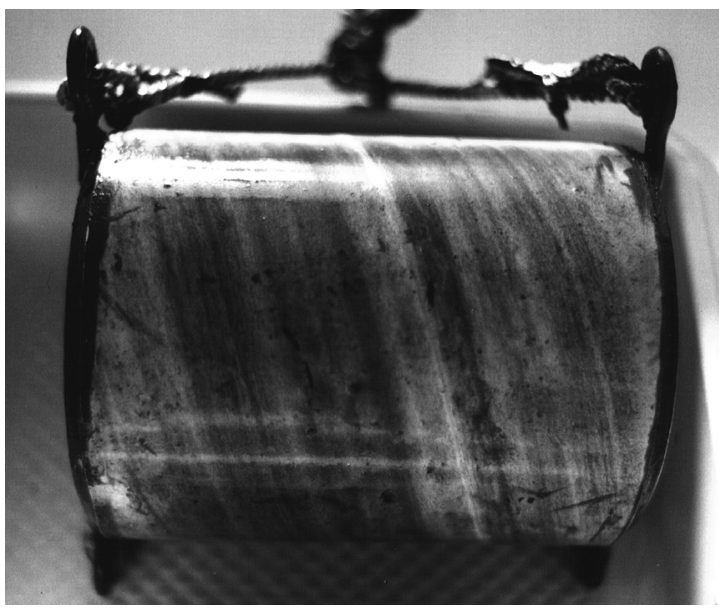

Figure 4. Pipe covered by saturated copper Coating $(A)$ after a month of immersion. Can be observed the loss of cupper coating.

\section{Figure 4. Caño cubierto por una capa saturada de cobre $(A)$ ldespués de un mes de inmersión. Puede observarse el desprendimiento de la ca- pa de cobre.}

Tables II and III show the counts of sessile bacteria from the monthly sampled series and the accumulative series (immersed during six months) of control panels and saturated copper coating panels (B), respectively.

The control panels subject to both monthly and accumulative exposition presented high microbial densities corresponding to the biofilm. Heterotrophic bacteria were observed in $10^{12} \mathrm{CFU} / \mathrm{cm}^{2}$ orders of magnitude, acid producing bacteria and anaerobic sulfate-reducing bacteria (SRB) were detected in orders of $10^{5} \mathrm{mo} / \mathrm{cm}^{2}$ (Tables II and III).

In the case of panels covered by the copper coating, only high levels of aerobic heterotrophic bacteria biofilm were detected for both monthly and accumulative six month exposure (Tables II and III). The presence of this biofilm could favor the adhesion of macofouling organisms in a period longer than six month. Neither fungi nor yeast were detected in either cases. After the six-month immersion, numerous macrofouling and microfouling species were observed in the control panel. This panel was dominated by solitary ascidians, which in turn provided suitable substrate for the settlement of other organisms such as algae (Enteromorpha sp. and Ectocarpus sp.), bryozoans, and tubeworms, as well as facilitating sediment deposition. Some barnacles, other bryozoans, and sand tube building worms were also recorded on the surface of the panel (Fig. 5).

With respect to the establishment of microfouling, a large amount of microfouling was observed 
Table II. Amounts of sessile bacteria recorded. Monthly sampling. $\mathrm{MC}$ : monthly control - MCu: monthly with copper coating (B) CFU cm-2: colony forming unit $\mathrm{cm}-2$ mo: microorganisms WG: without growth

Tabla II. Valores de bacterias sésiles registrados. Muestreo mensual. $M C$ : control mensual- MCu: mensual con cubierta de cobre (B) CFU cm-2: Unidades formadoras de colonias por $\mathrm{cm}-2$ Mo: microorganismos. WG: sin crecimiento

\begin{tabular}{lcccccc}
\hline \multirow{2}{*}{$\begin{array}{c}\text { Microorganisms } \\
\text { Sampling }\end{array}$} & $\begin{array}{c}\text { Heterotrophic aerobic } \\
\text { bacteria (CFU cm }\end{array}$ & MC $)$ & $\begin{array}{c}\text { Acidifying activity } \\
\text { bacteria (Mo cm }\end{array}$ & \multicolumn{2}{c}{$\begin{array}{c}\text { SRB } \\
\left(\mathrm{Mo} \mathrm{cm}^{-2}\right)\end{array}$} \\
\cline { 2 - 7 } & MCu & MC & MCu & MC & MCu \\
\hline February/March & $300 \times 10^{6}$ & $160 \times 10^{5}$ & 100 & WG & 100 & WG \\
March/April & $244 \times 10^{8}$ & $60 \times 10^{8}$ & 100,000 & WG & 1,000 & WG \\
April/May & $100 \times 10^{12}$ & $245 \times 10^{8}$ & 10,000 & WG & 1,000 & WG \\
May/June & $33 \times 10^{10}$ & $30 \times 10^{7}$ & 1,000 & WG & 10,000 & WG \\
June/July & $69 \times 10^{10}$ & $97 \times 10^{9}$ & 1,000 & WG & 100,000 & WG \\
July/August & $168 \times 10^{10}$ & $74 \times 10^{7}$ & 100 & WG & WG & WG \\
\hline
\end{tabular}

Table III. Amounts of sessile bacteria recorded. Accumulative sampling (six-month immersion). AC: accumulative control - ACu: accumulative with copper coating (B).

CFU cm-2: colony forming unit $\mathrm{cm}-2$

Mo: microorganisms. WG: without growth

Tabla III. Valores de bacterias sésiles registrados. Muestreo acumulativo (seis meses de inmersión).

AC: control acumulativo- ACu: acumulativo con cubierta de cobre (B)

CFU cm-2: Unidades formadoras de colonias por $\mathrm{cm}-2$

Mo: microorganismos. WG: sin crecimiento

\begin{tabular}{lcccccc}
\hline \multirow{2}{*}{$\begin{array}{c}\text { Microorganisms } \\
\text { Sampling }\end{array}$} & \multicolumn{2}{c}{$\begin{array}{c}\text { Heterotrophic aerobic } \\
\text { bacteria (CFUcm }\end{array}$} & $\begin{array}{c}\text { Acidifying activity } \\
\left.\text { bacteria(Mo } \mathbf{~ c m}^{-2}\right)\end{array}$ & \multicolumn{2}{c}{$\begin{array}{c}\text { SRB } \\
\left(\mathrm{Mo} \mathrm{cm}^{-2}\right)\end{array}$} \\
\cline { 2 - 7 } & AC & Acu & AC & Acu & AC & ACu \\
\hline February/March & $300 \times 10^{6}$ & $160 \times 10^{5}$ & 100 & WG & 100 & WG \\
February/April & $240 \times 10^{10}$ & $240 \times 10^{8}$ & 10,000 & WG & 1,000 & WG \\
February/May & $86 \times 10^{12}$ & $38 \times 10^{8}$ & 10,000 & WG & 1,000 & WG \\
February/June & $38 \times 10^{10}$ & $74 \times 10^{8}$ & 1,000 & WG & 10,000 & WG \\
February/July & $58 \times 10^{10}$ & $180 \times 10^{10}$ & 1,000 & 100 & 10,000 & WG \\
February/August & $65 \times 10^{10}$ & $97 \times 10^{7}$ & 10,000 & WG & 100,0000 & WG \\
\hline
\end{tabular}

including different species of diatoms, as corroborated by SEM (Fig. 6).

The panel covered with copper coating (B) did not show macrofouling. Microscopic examination showed only a thin film dominated by a few diatom species on the lower half of the panel (Figs. 5 and 7). Although this cover is similar to (A), its good performance was due to the fact that it was handexpread and no copper leaching was observed.

The water of harbour presenting scarce removal and high pollution levels (low DO values $0,8 \mathrm{ml} / 1$ to $6.0 \mathrm{ml} / \mathrm{l}$, pH 7,56 to 8,30 , salinity $32 \%$ to $35 \%$ high content of suspended organic matter and sulfide). 
ANTIFOULING EFFECT OF TWO SATURATED COPPER COATINGS APPLIED ON CARBON STEEL STRUCTURES) EFECTO ANTIFOULING DE DOS CUBIERTAS SATURADAS DE COBRE APLICADAS SOBRE ESTRUCTURAS DE ACERO AL CARBONO

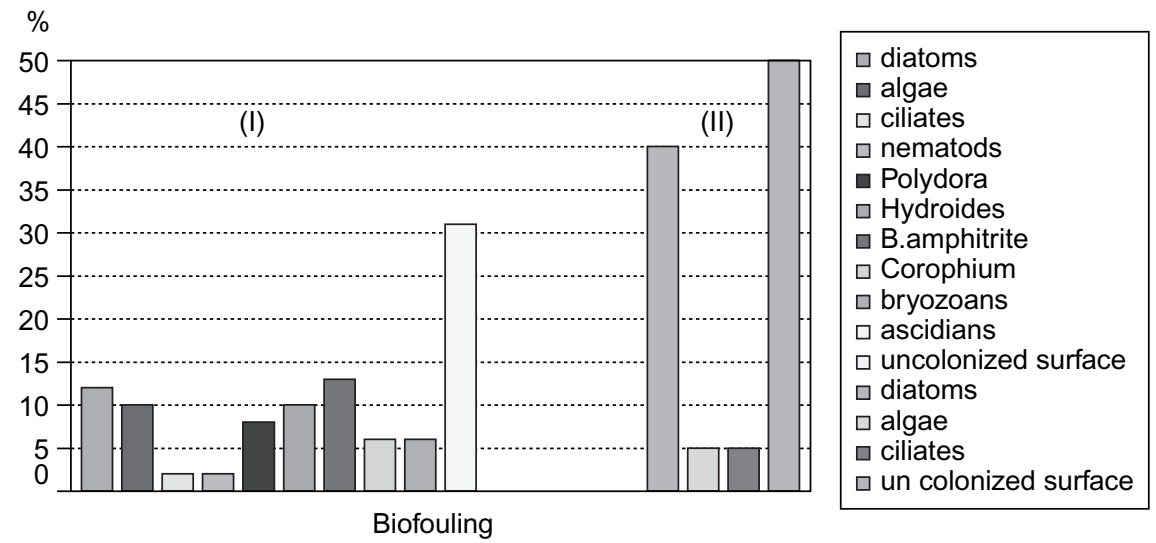

Figure 5. Cover percentage on control panel (I) and panel covered by saturated copper coating (B) (II) (6 months of immersion).

Figura 5. Porcentaje de cobertura en el panel control (I) y panel cubierto con una cubierta saturada de cobre (B) (II). (6 meses de inmersión).

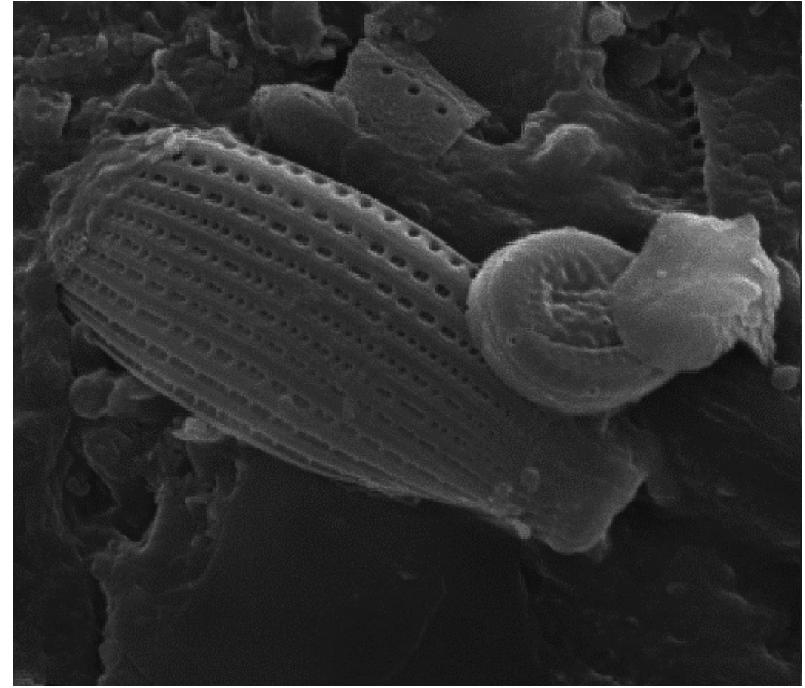

Figure 6. SEM micrograph showing diatoms corresponding to a panel with copper layer (B). (third month of immersion) $X 3500$. Image wide $18.08 \mu \mathrm{m}$.

Figura 6. Fotografía de MEB mostrando diatomeas correspondientes al panel cubierto por la capa de cobre saturado (B). (tres meses de inmersión) X 3500. Ancho de la imagen 18,08 $\mu \mathrm{m}$.

Abiotic factors (water and air temperature) varied during the course of this study. Water and air temperature was lower during the winter months. Air temperature was higher during the warm months principally February. The variations in microbial counts could be related to these conditions. The amount of heterotrophic bacteria was high, and even more so

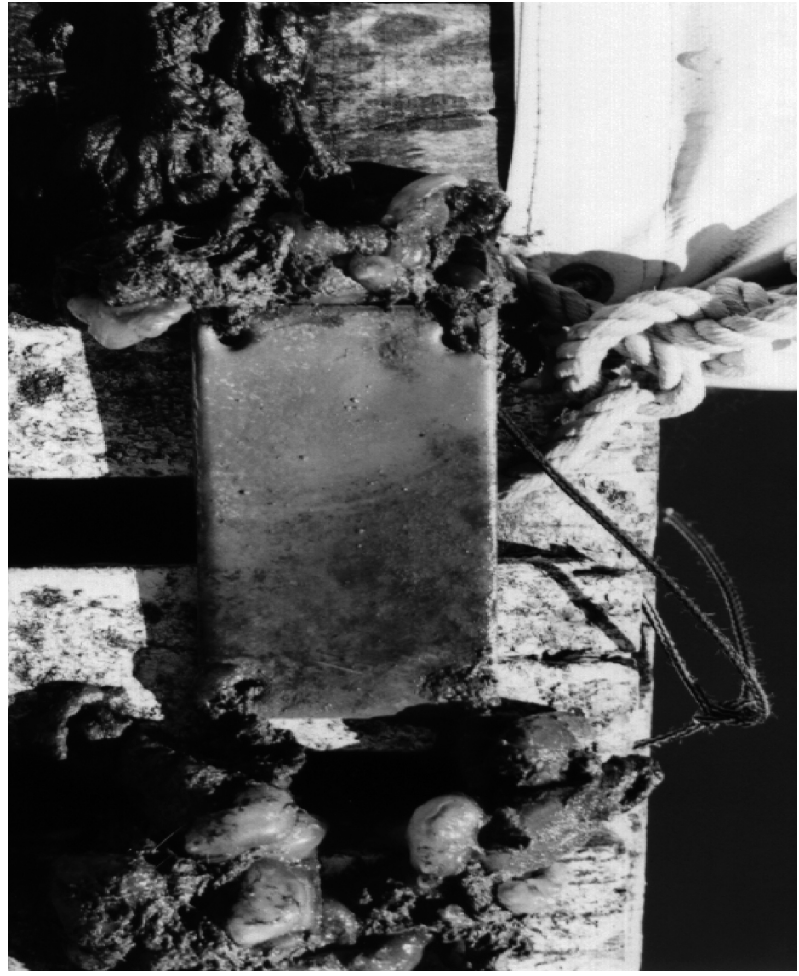

Figure 7. Panel covered by saturated copper coating (B) after six month of immersion.

Figura 7. Panel cubierto por la capa de cobre saturado $(B)$ después de seis meses de inmersión.

during the warmer months (Tables II and III). However, favorable conditions for microbial development in seawater can allow bacterial colonization to occur during longer periods (Table IV). 
Tabla IV. Factores Abióticos

Table IV. Abiotic factors

\begin{tabular}{lccccccc}
\hline & Feb. & Mar. & Apr. & May & Jun. & Jul. & Aug. \\
\hline Water temperature & $19.0^{\circ} \mathrm{C}$ & $22.8^{\circ} \mathrm{C}$ & $21.0^{\circ} \mathrm{C}$ & $14.7^{\circ} \mathrm{C}$ & $11.4{ }^{\circ} \mathrm{C}$ & $8.9{ }^{\circ} \mathrm{C}$ & $9.3^{\circ} \mathrm{C}$ \\
Air temperature & $27.7^{\circ} \mathrm{C}$ & $26.8^{\circ} \mathrm{C}$ & $21.8^{\circ} \mathrm{C}$ & $17.6{ }^{\circ} \mathrm{C}$ & $9.4{ }^{\circ} \mathrm{C}$ & $7.6{ }^{\circ} \mathrm{C}$ & $13.0^{\circ} \mathrm{C}$ \\
Conductivity & $47.8 \mathrm{mS}$ & $55.3 \mathrm{mS}$ & $47.6 \mathrm{mS}$ & $45.1 \mathrm{mS}$ & $43.8 \mathrm{mS}$ & $40.6 \mathrm{mS}$ & $42.7 \mathrm{mS}$ \\
$\mathrm{pH}$ & 8.00 & 8.30 & 7.94 & 8.03 & 7.56 & 7.63 & 7.80 \\
\hline
\end{tabular}

\section{CONCLUSIONS}

The panel covered with saturated copper coating (A) showed low antifouling performance after 6 months of accumulative exposure, in contrast with the panels exposed monthly during a period of six months. This was probably due to the loss of $\mathrm{Cu}$, which could be explained by either a high rate of leaching, or defective adhesion of the coating to the pipes determined by the type of treatment applied.

The panel covered with saturated copper coating (B) showed good antifouling performance after six months of immersion. This is evidenced by comparing the heavy fouling registered on the control panel vs. the thin film of microfouling organisms registered on this copper-coated panel. Nevertheless, both the samples with saturated copper coating (B) and the control showed important adherence of heterotrophic aerobic bacteria. This could favor the adhesion of macrofouling organisms in a period superior to the 6 months of this study. Future investigations will assess the progress of colonization during longer periods.

\section{Acknowledgements}

The authors acknowledge the financial support from CONICET (PIP 6075/05), and UNLP (11N 457) and CICBA ( 673/06).

\section{REFERENCES}

[1] W.G. Characklis and K.C. Marshall, Biofilm, Ed. John Wiley \& Sons, New York, USA, 1990, pp. 3-15.

[2] H.A. Videla, P.S. Guiamet, O.R. Pardini, E. Echarte, D. Trujillo and M.M.S. Freitas, Practical Manual of Biocorrosion and Biofouling for the Industry, M.D.Ferrari, M.F.L. de Mele y H.A. Videla (Eds.), CYTED, La Plata, Bs. As, Argentina, 1998, pp. 136-144.
[3] E.C. Hill, Microbial problems and corrosion in oil and oil product storage, John Wiley \& Sons, London, (England), 1983.

[4] E.C Hill, J.L. Shennan and R.J. Watkinson, Microbial problems in the offshore oil industry, Jhon Wiley \& Sons, Chichester, (England), 1987.

[5] I.B. Beech, Microbiol. Today. 30 (2003) 115 117.

[6] J.R. Postgate, The Sulphate-Reducing Bacteria, Ed. University Press, Cambridge, UK, 1984..

[7] R.G.J. Edyvean and H.A. Videla. Recent Advances in Biodeterioration and Biodegradation, K.L. Garg, N. Garg, K.G. Mukerji,. (Eds.) UK. 1994, II pp. 81-116.

[8] P.F. Sanders and W.A. Hamilton, Biologically Induced Corrosion, NACE-8, Ed. International Corrosion Conference, Houston, Texas (USA), 1986.

[9] K.M. Maxwell, K.M. Mclean and J. Kearns, Microbial Problems in the Off-Shore Oil Industry, Ed. Jhon Wiley \& Sons, Chichester, (UK),1987.

[10] I.P. Beech and J. Sunner, Curr. Opin. Biotech. 15 (2004) 181-186.

[11] J.W. Costerton, G.G. Geesey and P.S. Jones, Mater. Perform. 27 (1988) 49-52

[12] S.G. Gómez de Saravia and P.S. Guiamet, Rev. Metal. Madrid 39 (2003) 1-5.

[13] H.A. Videla, P.S. Guiamet, S G. Gómez de Saravia, L.K. Herrera, and C. Gaylarde, CORROSION/2004, paper No 04574, NACE International, Houston, TX, (USA), 2004.

[14] S.G. Gómez de Saravia, Tesis Doctoral, Facultad de Ciencias Naturales y Museo, Universidad Nacional de La Plata, 1991.

[15] H.A. Videla, S.G. Gómez de Saravia and M.F.L. De Mele. CORROSION/92, paper No 189, NACE International, Houston, TX, (USA), 1992.

[16] H.A. Videla, Int. Biodeter. Biodegr. 34 (1994) 245-252.

[17] W. Wang, J. Wang, X. Li, H. Xu and J. Wu, Werkst. Korros. 55 (2004) 30-35. 
[18] H.A. Videla, Practical Manual of Biocorrosion and Biofouling for the Industry, M.D.Ferrari, M.F.L. de Mele y H.A. Videla (Eds.), CYTED, La Plata, Bs. As, Argentina, 1998, pp. 4-26.

[19] M.T. Madigan, T.J.M. Martinko and J. Parker. Brock A. Biología de los microorganismos, Pearson Educación, S.A., Madrid (España), 2004.

[20] P.S. Guiamet, S. Gómez de Saravia, P. Arenas, M.L. Pérez, J. De La Paz and S. F. Borrego, Pharmacologyonline 3 (2006) 534-544.

[21] S. Pezzani, M. Perez and M. Stupak, Corros. Rev. 14 (1996) 1-2.

[22] S.G. Gómez de Saravia, P.S. Guiamet and H.A. Videla, IV Congreso Iberoamericano de Corrosión y Protección. Vol. 2, Mar del Plata, (Argentina), 1992, Rascio, V. (Ed.), CIDEPINT, La Plata, (Argentina), 1992, 381-389.

[23] S.G. Gómez de Saravia and P.S. Guiamet, V Jornadas Nacionales del Mar. XIII Coloquio Argentino de Oceanografía, Mar del Plata (Argentina), 2003b, UNMar del Plata, (Argentina), 2003, 115.

[24] M.R.G. de Chialvo, R. Salvarezza, D.VasquezMoll and A.J. Arvia, Electrochim. Acta 30 (1985) 1501-15011.

[25] T. Senthilvelan, K. Raghukandan and A. Venkatraman, J. Mater. Process. Technol. 153-154 (2004) 420-423. 